\title{
Theoretical and Numerical Studies on Viscoelastic Effect in Phase Separation of Polymeric Systems
}

\author{
Takashi TANIGUCHI \\ Polymer Science and Engineering, Yamagata University \\ Jonan 4-3-16, Yonezawa, Yamagata, 992-8510, Japan
}

\begin{abstract}
Viscoelastic effects on phase separations in polymeric systems are investigated by a numerical method using a two fluid model. In the viscoelastic phase separation, the coupling of solvent diffusion and stress stored in polymeric materials strongly influences the dynamics, morphology of phase separated pattern. In our model we take into account the coupling and explain unusual phase separation phenomena observed experimentally in polymer solution systems. In our simulations, we reproduced the network pattern of polymer rich phase which is a minority phase and found that the coarsening of the network pattern is very slow. In order to clarify the origin of slowing down of coarsening dynamics of network pattern of polymer rich phase,we investigated the dynamics of an initially elongated droplet. We found that the flow field induced by the surface tension of droplet is suppressed by the stress produced by the induced flow field.
\end{abstract}

Key Words: Two fluid model / Viscoelastic phase separation

\section{高分子系の相分離における粘弾性効果の理論および 計算機シミュレーションによる研究}

谷口 貴志

（原稿受理：2003年11月24日）

\section{1. 諸言}

高分子系の相分離の従来の研究では，その相分離の低分子 二成分流体系との類似性，つまり普遍的性質に高い関心が向 けられて来たが，高分子系が有する粘弾性が，相分離にどの ような影響を与え, どのような違いを生じさせるかという視 点からの研究は少なかった. しかし, 高分子溶液系や高分子 混合系で低分子二成分流体系とは全く違った相分離現象が


高分子溶液をFlory-Hugginsの自由エネルギーを対応させて考 えた場合の 2 相共存領域内の不安定領域へ急冷したことに なっているにも拘らず，初期過程において，不安定モードの 増大が著しく遅い, すなわち, 不安定化するのに非常に長い 時間を要する凍結状態 (frozen state) が観測された. また, 後 期の相分離過程も通常の（表面張力によって支配される）動 的過程と著しく異なり, 高分子リッチ相のネットワークが形 成され，ドメインの成長指数も低分子二成分流体系のものに 比べ著しく小さいなど，驚くべき動的性質が観測された。こ のような特異な相分離過程は低分子系にはない高分子系の 固有の特徴である “絡み合い”に由来する粘弾性効果が相分
離した二相の中の一方に著しく影響を及ぼす（すなわち動的 非対称性が存在する）ためであると考えられている.

また，臨界温度より高温の一相状態にある高分子溶液にせ 儿断流動を印加すると，ある特定の条件下では濃度摇らぎが 誘起され，明確な相分離が起こるという実験結果が報告され ている.この現象は流動誘起相分離 ${ }^{2}$ と呼ばれている.この 現象も，高分子同士の絡み合いに起因する応力場と濃度場の 拡散が深く関係し合った現象であり，粘弾性効果が重要な役 割を演じていると考えられている.

この応力と拡散の結合は高分子溶液系のみならず，ゲルの 体積相転移のダイナミクスにも大きな影響を及ぼすと考え られる．膨潤相から収縮相への温度ジャンプによる収縮過程 では，表面スキン層の形成，収縮の一時停滞現象，様々な内 部構造の出現など非常に興味深い現象が出現するが，これら は，ネットワーク共同拡散モデルでは説明できていない.こ れらの現象にも「溶媒拡散と内部応力の結合」が重要な役割 を果たしていると考えられる. ${ }^{31}$

以下で述べる研究成果は，通常の低分子系での相分離現象 と違うこの特異な相分離現象の本質を理解することを目的 として行ったものである. 


\section{2. モ デル}

諸言で述べたように，高分子溶液系で見られる通常とは 違つた相分離や流動誘起相分離では, 高分子同士の絡み合い とその緩和過程が本質的な役割を演じると考えられる.ここ では，そのような高分子同士の絡み合いを記述するために， 二階のテンソル場 4$), W_{i j}$ を導入する.

この $W_{i j}$ の意味を理解するために, 位置 $\boldsymbol{r}$ ある微小体積中 の高分子 $\alpha$ を考えよう.この高分子 $\alpha$ 他の高分子と一時的に 絡み合っている点の集合 $\boldsymbol{R}_{n}$ (Fig.1参照) を用いると, 高分子 $\alpha$ に関する $W_{i j}^{\alpha}$ は以下のように書ける. ${ }^{4}$

$$
W_{i j}^{\alpha}(\boldsymbol{r})=\sum_{n=1}^{z}\left(\boldsymbol{R}_{n+1}-\boldsymbol{R}_{n}\right)_{i}\left(\boldsymbol{R}_{n+1}-\boldsymbol{R}_{n}\right)_{j} / a^{2} N_{e} z
$$

ここで $z$ は高分子 $\alpha$ 上の絡み合い点の数, $N_{e}$ は絡み合い点間分 子量, $a$ はセグメントサイズである. $W_{i j}(\boldsymbol{r})$ は位置 $\boldsymbol{r}$ 微小体積 中にある高分子に関する平均として定義する.

Figure 2を見て分かるように, 変形と $W_{i j}$ テンソルが密接に関 係していることが分かる．例えば，Fig.2の下段のような瞬間 的な変形に対し, 高分子が $x$ 方向に引き伸ばされると $W_{x x}-1>0$, 押し縮められると $W_{x x}-1<0$ となることが分かる. このように 場の変数 $W_{i j}$ は高分子の絡み合い点間の構造の歪みを表現す るテンソルである.

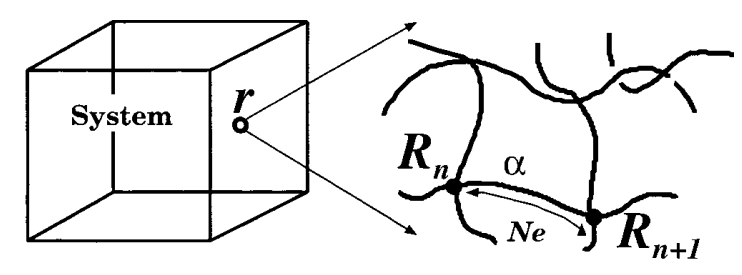

Fig.1 Schematic picture of temporal entanglements of polymer chains. $\boldsymbol{R}_{n}$ and $\boldsymbol{R}_{n+1}$ denote position vectors of successive entanglement points on a polymer chain.
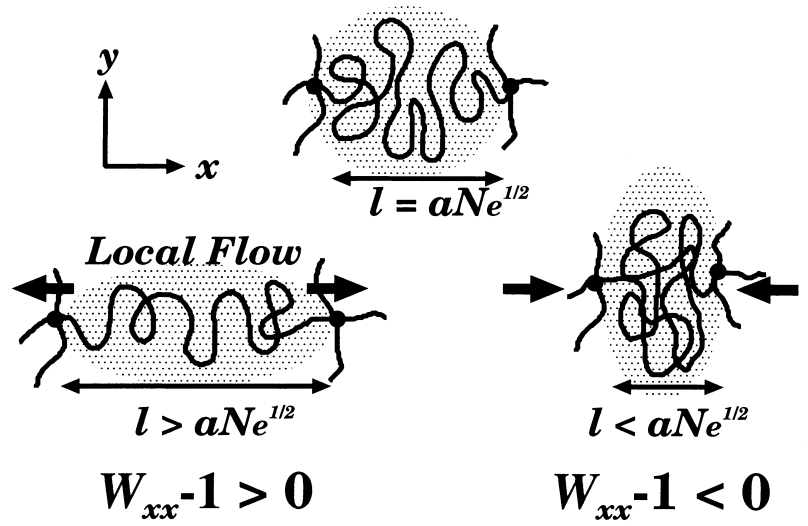

Fig.2 Relation between local deformations of an entangled polymer chain and the values of conformation tensor $W_{x x}$.
今まで高分子溶液系，高分子混合系等で通常の相分離と異 なった現象が観測1)されているが，ここでは高分子溶液系を 対象に話を進めていくことにする．高分子の絡み合いによっ て生じる “一時的な” 高分子ネットワークの歪みを表す $W_{i j}$ と 高分子の局所体積分率 $\phi$ を使って，この系を記述する自由エ ネルギー汎関数 $F[\phi, \mathrm{W}]$ は

$$
F=\int d \mathbf{r}\left[\frac{1}{2} C(\phi)(\nabla \phi)^{2}+f(\phi)+f_{\mathrm{el}}(\phi, \mathrm{W})\right]
$$

と書くことが出来る.ここで， $C(\phi)$ の項は界面エネルギーを 表寸項で, 乱雑位相近似から $C(\phi)=C_{o} / \phi, f(\phi)$ は次式のFloryHugginsの混合の自由エネルギー密度

$$
f(\phi)=\frac{k_{B} T}{a^{3}}\left[\frac{\phi}{N} \log \phi+\left(\frac{1}{2}-\chi\right) \phi^{2}+\frac{1}{6} \phi^{3}\right]
$$

である。ここでNは重合度， $k_{B}$ はボルツマン定数，Tは温度，

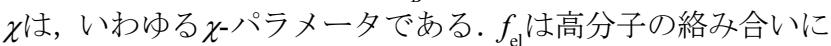
よってできる一時的な高分子網目の歪みに由来する弾性工 ネルギーで，次のように書くことが出来る.

$$
\begin{aligned}
f_{\mathrm{el}}(\phi, \mathrm{W}) & =\frac{1}{4} G(\phi) Q_{1}(\mathrm{~W})+\frac{1}{8} \lambda(\phi) Q_{2}(\mathrm{~W}) \\
Q_{1}(\mathrm{~W}) & \equiv \frac{1}{2} \operatorname{Tr}\left(\delta \mathrm{W}-\delta_{i j}(\operatorname{Tr} \delta \mathrm{W})\right)^{2} \\
Q_{2}(\mathrm{~W}) & \equiv \frac{1}{2}(\operatorname{Tr} \delta \mathrm{W})^{2} \\
\delta W_{i j} & \equiv W_{i j}-\delta_{i j}
\end{aligned}
$$

ここで， $G(\phi)$ はせん断弾性率， $\lambda(\phi)$ は体積弾性率である．ダ イナミクスを支配する方程式は, 高分子の絡み合いによって できる一時的な高分子網目の歪み, つまり, 高分子ネット ワークの応力と高分子の拡散が結合した二流体モデルに よって記述することが出来る. 高分子と溶媒の速度をそれぞ れ $\boldsymbol{v}_{p}, \boldsymbol{v}_{s}$ とし，それらの平均速度を $\boldsymbol{v}$ とする. 高分子溶液系の臨 界組成 $\phi_{c}$ からそれほど離れていない場合を考えるなら高分子 の体積分率 $\phi$ に対し $\phi \ll 1$ が成り立ち， $v_{p}$ は体積分率の摇らぎ に由来する応力 $\Pi^{\phi}$ と一時的に絡み合った高分子に由来する 弾性応力 $\Pi^{\mathrm{el}}$ を使って

$$
\boldsymbol{v}_{p}=\boldsymbol{v}+D_{1}\left[-\nabla \cdot \Pi^{\phi}-\nabla \cdot \Pi^{\mathrm{el}}\right] / \phi^{2}
$$

と書ける ( $D_{1}$ はモノマーの拡散係数). 高分子の局所体積分 率 $\phi$ 対する方程式は，連続の方程式より決まり

$$
\frac{\partial \phi}{\partial t}=-\nabla \cdot(\boldsymbol{v} \phi)+D_{1} \nabla \cdot\left[\frac{1}{\phi}\left(\nabla \cdot \Pi^{\phi}+\nabla \cdot \Pi^{\mathrm{el}}\right)\right]
$$


である.速度場 $\boldsymbol{v}$ に対する運動方程式は二流体方程式とストー クス近似を用いて

$$
\eta_{s} \Delta \boldsymbol{v}=-\nabla p+\nabla \cdot \Pi^{\phi}+\nabla \cdot \Pi^{\mathrm{el}}
$$

と書ける. 絡み合い点間の構造の歪みを表すテンソル $W_{i j}$ の時 間発展は, 高分子速度の勾配によってネットワークに歪みを 生じさせる項と, レプテーションによる緩和を表す項からな る次の方程式で記述される.

$$
\begin{aligned}
& \frac{\partial W_{i j}}{\partial t}+\left(\boldsymbol{v}_{p} \cdot \nabla\right) W_{i j} \\
& =\frac{\partial v_{p i}}{\partial x_{k}} W_{k j}+W_{i k} \frac{\partial v_{p j}}{\partial x_{k}}-\Gamma_{i j k l} \frac{\delta F}{\delta W_{k l}} \\
& \Gamma_{i j k l}=\frac{\Gamma}{2}\left(\delta_{i k} \delta_{j l}+\delta_{i l} \delta_{j k}-\frac{2}{d} \delta_{k l} \delta_{i j}\right)+\frac{\Gamma}{d^{2}} \delta_{k l} \delta_{i j}
\end{aligned}
$$

ここで, $\Gamma_{i j k l}$ は緩和係数である. $W_{i j}$ の緩和は高分子のレプテー ション運動によるものであるとすると，その特徵的緩和時間 $\tau$ は $\tau \sim 1 / \Gamma \sim \tau_{b}\left(N_{\mathrm{e}} / N\right)^{\alpha}=N^{\alpha} \phi^{\frac{\alpha-3}{3 k-1}}$ である（ $\alpha$ は実験值3.4，レプ

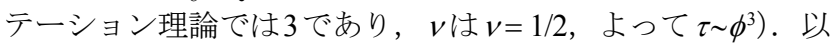
下では，これらの方程式を用いて行った数值計算の結果につ いて述べて行く.

\section{3. 数值計算結果 一粘弾性相分離一}

上述の運動方程式(8), (9), (10)を用いて一様混合状態から 二相領域にクエンチした後の相分離ダイナミクスのシミュ レーション（高分子の体積分率 (I) $30 \%$ (II) $25 \%$ ) を行なった. シミュレーションで用いた空間スケール $l$ は $l=\left(N C_{o}\right)^{1 / 2} / 4 て ゙$, 時 間スケール $t_{o}$ は $t_{o}=l^{2} \sqrt{N} / D_{1}$ である. 以下で用いられる無次元距 離と時間は，これらでスケールされたものである．計算に用

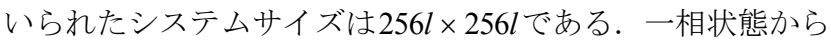
クエンチした二相状態の位置は $(2 \chi-1) \sqrt{N}=4.25$ である. Fig.3
(I)

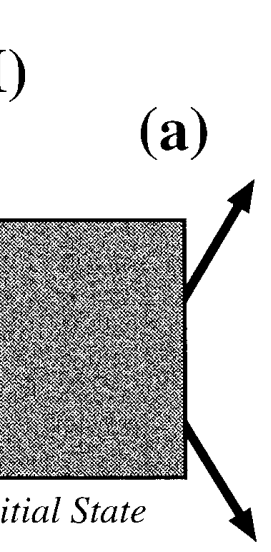

(b)

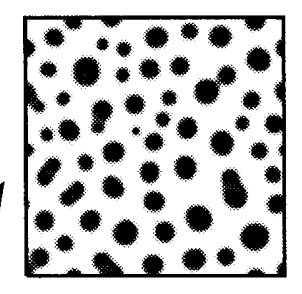

$t=100$

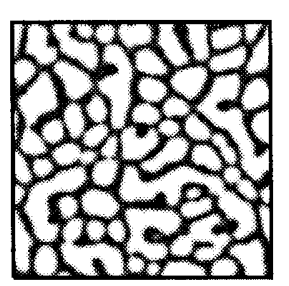

$t=100$

(II)

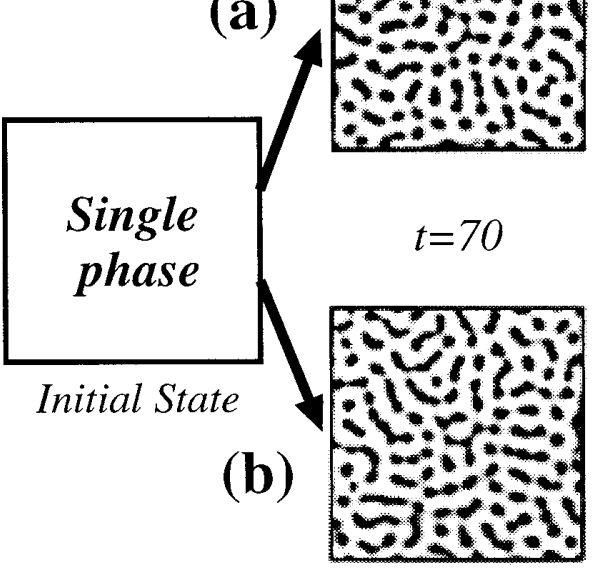

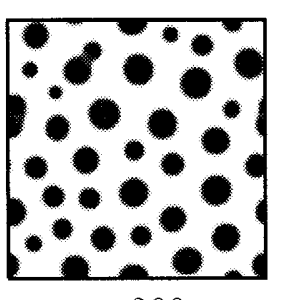

$t=300$

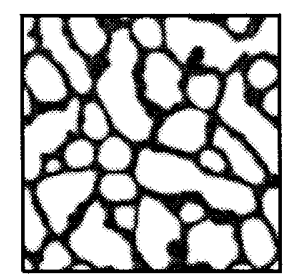

$t=300$

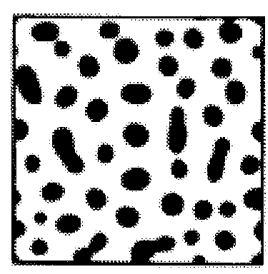

$t=150$

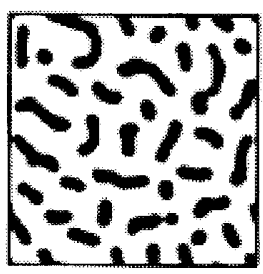

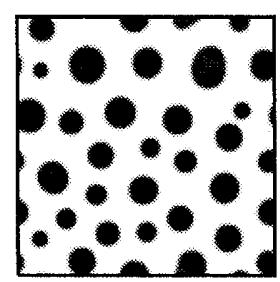

$t=500$

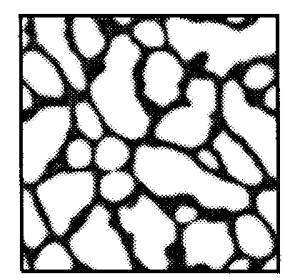

$t=500$

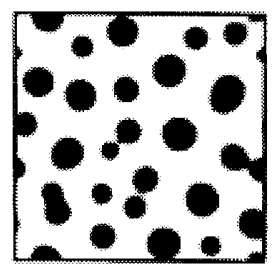

$t=300$

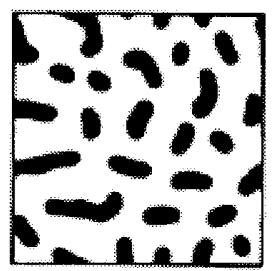

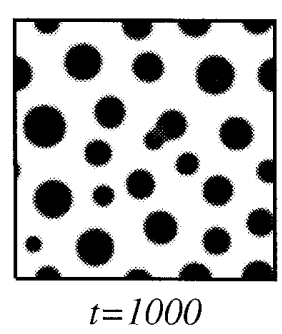

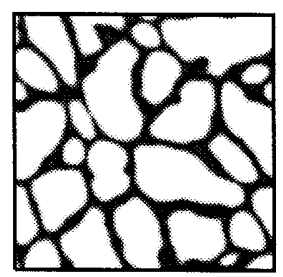

$t=1000$

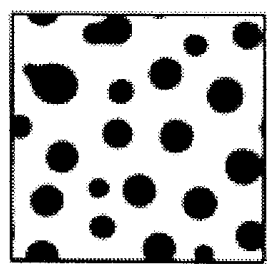

$t=500$

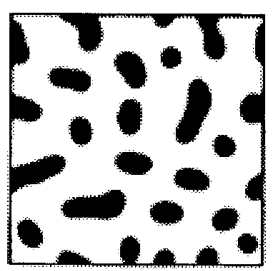

Fig.3 Time sequential snapshots of phase separation of (I-a) viscous and (I-b) viscoelastic systems with the average volume fraction $\bar{\phi}=0.3$, and (II-a) viscous and (II-b) viscoelastic systems with $\bar{\phi}=0.25$. The two cases (a) and (b) in (I) and (II) start from the same initial condition. The black domain denotes the polymer rich phase. 
に，その結果得られた粘弾性相分離のパターンの典型的時間 発展を示す. また, 比較を行うため, 全く同じ初期条件を用 いて, 絡み合い効果の全くない場合（低分子混合系に対応寸 る（以後, 二成分流体系と呼ぶ））のシミュレーションの結 果も合わせて示している. Fig.3から分かるように高分子の絡 み合いの効果が全くない場合（Fig.3のI (a) と II (a)）では高分 子リッチ相は界面張力の効果により, すぐに円形ドメインを 形成し，合体と拡散によって成長していく．合体直後は表面 張力によって引き起こされる流れ場による $\phi$ の流体力学的輸 送により短時間で円形ドメインを形成する。これは界面エネ ルギー駆動型の粗大化ダイナミクスである. 一方, Fig.3のI (b)の二成分粘弾性相分離では, 高分子リッチ相の体積分率が 小さい（ $\phi=0.3 ）$ にも拘らず高分子リッチ相がネットワーク を形成して，それが非常に長い時間安定に存在していること が分かる.このような体積分率が一方に偏った場合のネット ワーク構造の形成は, 低分子混合系では全く見られないもの である.このシミュレーションで得られた高分子リッチ相の ネットワークは, 実験1) で異常な相分離 (Unusual Phase Separation）として観測されているものに対応する. この相分 離の進行と共に形成された高分子リッチ相のネットワーク 構造では，ネットワーク間に働いている力の釣り合いにより 構造が決まっているように見える. 実際, シミュレーション の結果を動画として観察するとネットワークの枝がちぎれ るとネットワークに大きな変形が起こり, Fig.4のような力の 釣り合いが成立する構造へと進んで行く様子が観察できる.

このように, 粘弾性相分離での網目構造の粗大化の過程 は，高分子リッチ相で形成しているネットワークが “ちぎ れ”，そこに生じる突起状部分が緩和することにより進行す る. ネットワークがちぎれた後にできる突起状部分は非常に 長い間緩和せずに存在しており, 界面張力の効果がほとんど 機能していないことが分かる. これは，二成分流体系で粗大 化の源であった表面張力エネルギーよりも高分子ネット ワークに蓄えられる弾性エネルギーの効果が支配的である ことを示唆している. しかしながら高分子リッチ相内に蓄え られた弾性エネルギーは高分子のレプテーション運動によ り緩和し, 粗大化の最終ステージでは界面張力が支配的とな る.このシミュレーションの時間範囲内ではそのステージに までは到達していない.

粘弾性相分離では, 界面張力の効果がほとんど機能してい ないことは, Fig.3のII (b)の結果からも分かる.この場合には,

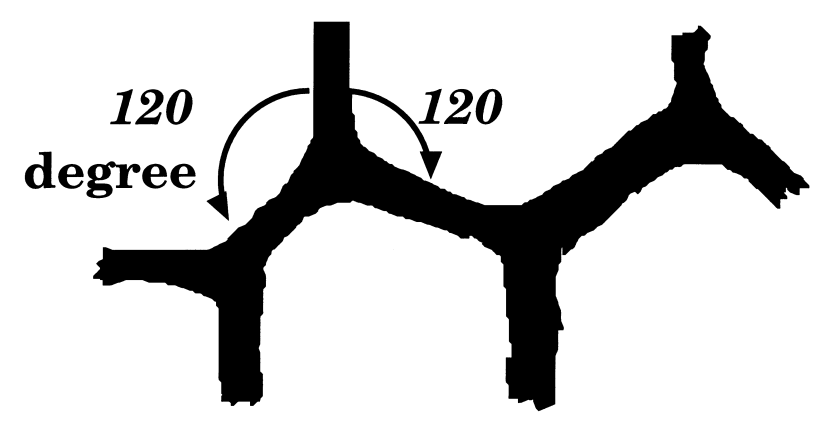

Fig.4 Mechanical force balance among strands in the network of polymer rich phase.
粘弾性効果がある系も無い系も，一相状態から二相分離状態 ヘクエンチした後に形成されたドメインが合体し，長細いド メインが出現する. 粘弾性効果が無い場合には, 長細いドメ インはすぐに円形状のドメインへ変形するのに対し，II(b)の 粘弾性効果がある系は非常に長い時間にわたって，この細長 いドメインが安定に存在する。この理由を詳しく調べるため に, II (b)の場合の無次元時刻 $t=140$ での, $W_{x x}$ の場の值を Fig.5 に示す. Fig.5から，長細いドメインの長軸方向が $x$ 軸方向 $(y$ 軸方向）を向いている場合には, ドメイン中央部での $W_{x x}-1$ の 值が負（正）であることが分かる．それを分かりやすく表し たのがFig.6である. Fig.6に示すように, 界面の曲率の絶対值 が最も大きなところで表面張力による流れがドメインの内 向き方向に生じ，それが高分子の絡み合いに由来する一時的 なネットワークの変形（伸長や圧縮）を引き起こしていると 考えられる.つまり, Fig.6の(a)の場合には, ドメイン内でy 軸に沿ってドメインの内向き方向に流れが生じ, ドメイン中 央部で $x$ 軸に沿ってドメインの外向き方向へ流れ場が出来る ため, $y$ 方向へ押し縮められ $\left(W_{y y}-1<0\right), x$ 方向へは引き伸ば され $\left(W_{x x}-1>0\right),(\mathrm{b})$ の場合には， $x$ 軸に沿ってドメインの内 向き方向に流れが生じ, ドメイン中央部で $y$ 軸に沿ってドメ インの外向き方向へ流れ場が出来るため, $x$ 方向へ押し縮めら れ $\left(W_{x x}-1<0\right), y$ 方向へは引き伸ばされている $\left(W_{y y}-1>0\right)$ と 考えられる.

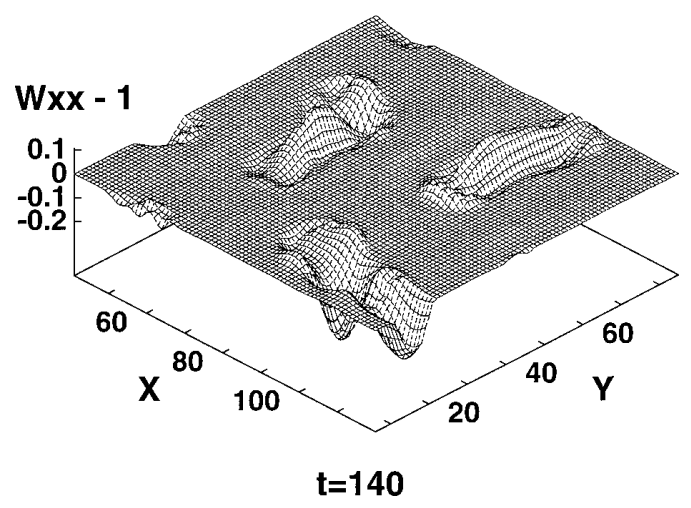

Fig.5 The $x x$-component of conformation tensor W. In the positive region of $W_{x x}$, the temporal polymer network is stretched along the $x$-direction by the flow induced by surface tension. In the region where $W_{x x}$ is negative, the polymer network is compressed along $x$-direction.

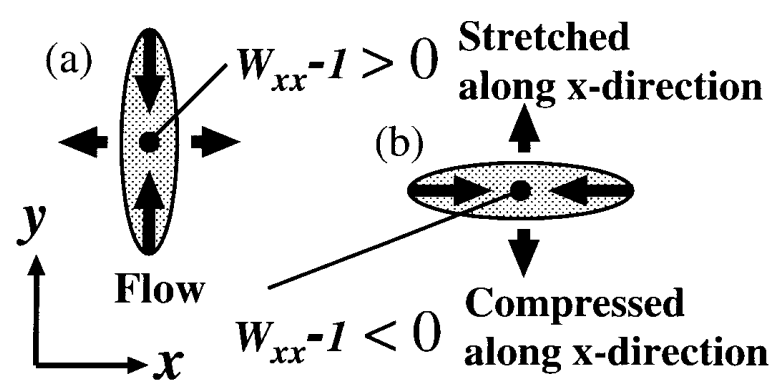

Fig.6 Schematic view of flow fields induced by surface tension and the value of $W_{x x}$ in elongated domains. 


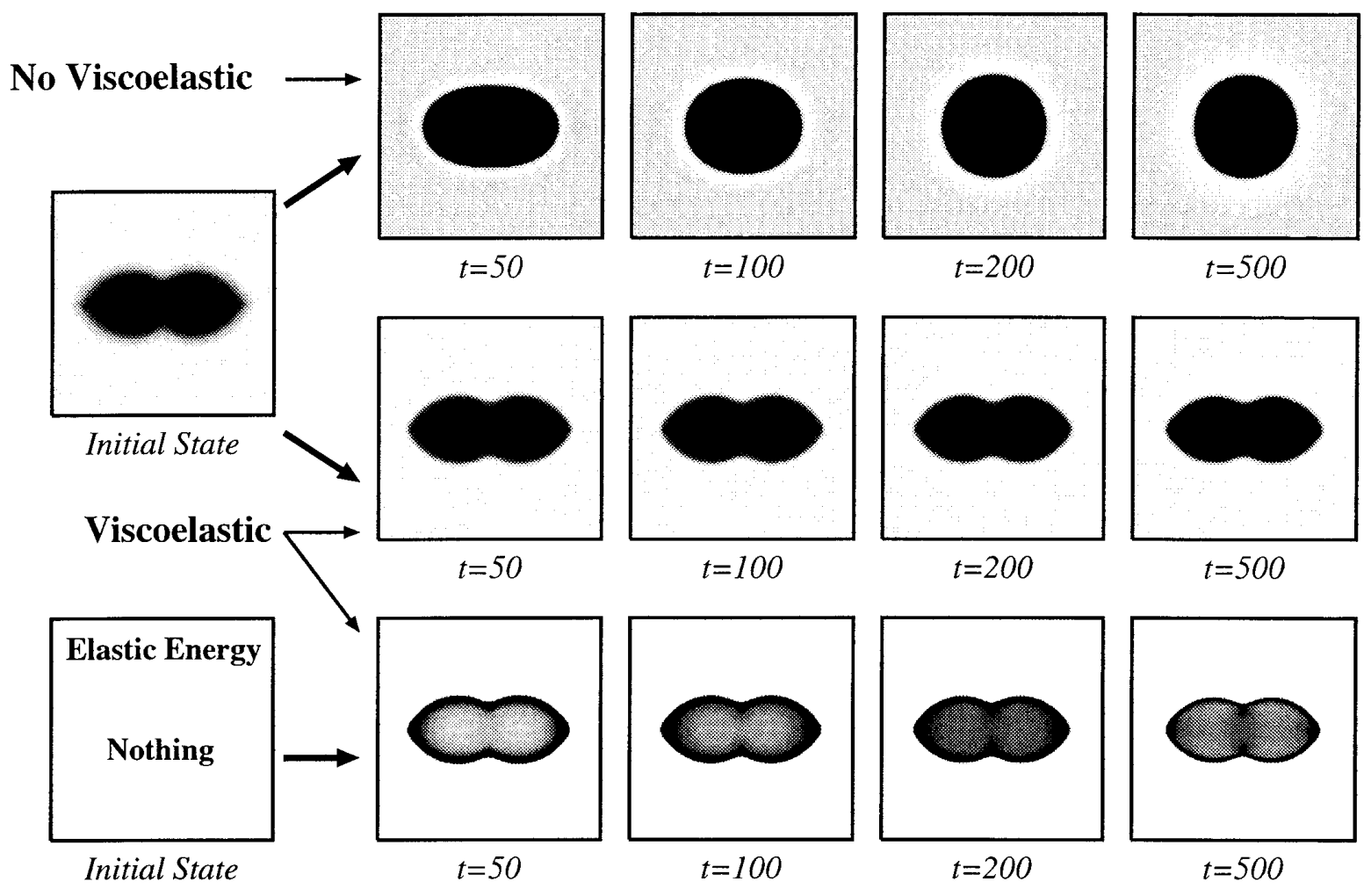

Fig.7 Time evolution of an elongated domain of polymer rich phase. In order to investigate viscoelastic effects on the coarsening process of phase separated patterns,we put an elongated domain as an initial state which does not have an elastic energy initially. In the viscous case, due to the induced flow field by the surface tension of the droplet, the elongated domain quickly goes back to the circular shape. The figures in the bottom line represent the stored elastic energy which is produced by the capillary flow.

このことを検証し，二成分流体系の相分離と粘弾性相分離 の違いをより詳細に理解するために，細長いドロップレット を初期条件として与えた場合のシミュレーションを行った (Fig.7). 粘弾性系では初期状態として高分子リッチ相内で高 分子ネットワークが完全に緩和しているとした（初期状態で は弾性エネルギーがゼロ). Fig.8に, 無次元時刻 $t=50$ での流 れ場の様子を示寸。このFig.8からも分かるように，二成分流 体系ではドメインの長軸の先端部の曲率の大きな部分が流 れ場を生じさせる主要な源となり長軸に沿ってドメイン内 向き方向に大きな流れ場が生じる.この流れ場による $\phi$ の輸 送により長細いドメインは急速に円形ドメインに緩和して いく. 一方, 粘弾性系でも初期条件として弾性場がゼロと設 定したので二成分流体系と同様に表面張力効果により流れ 場が生じるのだが，すぐにその流れ場はテンソル場 $W_{i j}$ の $\delta_{i j}$ か らのずれを誘起する（Fig.7の最下段参照）。つまり, 高分子 リッチ相内の一時的に絡み合った高分子網目に歪みを生じ させる. そのため高分子リッチ相内に応力場が発生し, 表面 張力により発生した流れ場を抑制しようと働く。この2つの

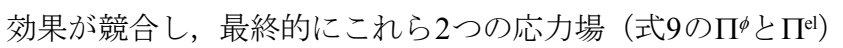
の釣り合いが成り立ち, 流れ場（の勾配）が小さくなるまで 歪夕場は生成され続ける. 最終的に, 流れ場を発生させる応 力項は互いに相殺しあい, 表面張力により誘起されるはずで あった流れ場は高分子の一時的な絡み合いに由来する応力 場により抑圧されてしまうことになる。
Figure 9 細長いドロップレットの緩和の場合の速度場の 絶対值 $|\boldsymbol{v}|$ の空間平均の時間発展のグラフを示す. 二成分流 体系と二成分粘弾性体では速度場の絶対值に明らかな違い があることが分かる. 以上から粘弾性相分離でのドメインの 粗大化の速度の著しい低下は界面の表面張力によって生じ る高分子の流れが高分子同士の絡み合いを引き起こし，それ が表面張力の効果をキャンセルしてしまうことによるもの であることが分かる. ${ }^{4)}$
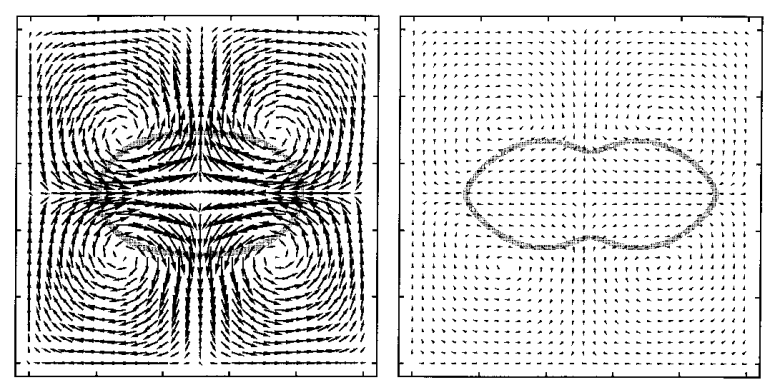

Fig.8 Velocity fields for no viscoelastic case (Left) and viscoelastic case (Right) at a dimensionless time $t=50$ in Fig.7. In both figures, arrows represent the flow field whose values are magnified one hundred times as large as the originals. The solid lines denote the domain boundaries. 


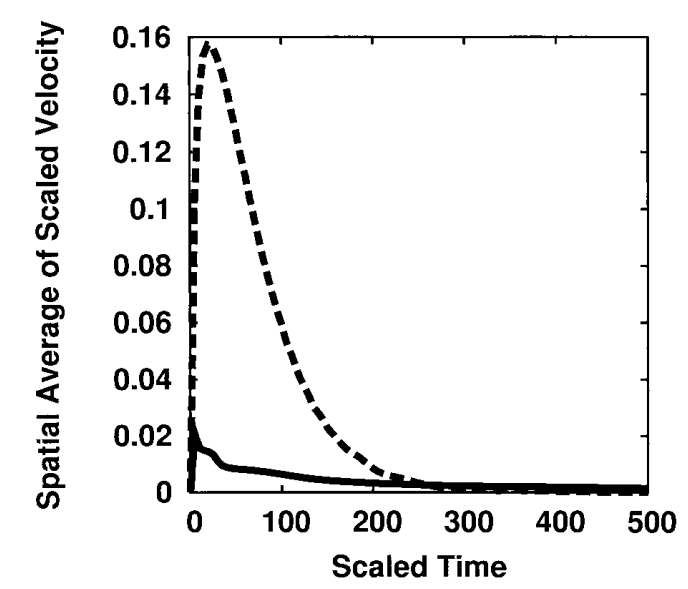

Fig.9 The spatial average of absolute value of the velocity field $|\boldsymbol{v}|$ in Fig.7. The dashed line denotes the data for the viscous elongated droplet, the solid line is the data for the viscoelastic one. In viscous system, the velocity field induced by the surface tension of droplet is larger than that in viscoelastic system. On the other hand, in viscoelastic system, the velocity field is also induced by the surface tension, but the velocity field is highly suppressed by an elastic field stored in the polymer rich region.

\section{4. まと め}

粘弾性効果と応力-拡散結合を取り入れたモデルを用い, 数 值計算の手法を用いて, 実験で観測された特異な相分離現象
を再現し理解することが出来た。この研究で用いたモデル は, 実験で観測された少数相である高分子リッチ相のネット ワーク構造形成を再現し，また後期過程でのドメインの粗大 化の速度が著しく小さくなることを再現した．また，この系 の実験で観測されたドメインの成長の速度の低下は，界面張 力によって生じる高分子の流れが高分子同士の一時的な絡 み合いによって生じるネットワークの歪みを引き起こし，そ れが表面張力の効果と競合し，互いに相殺しあって流動を抑 制してしまうことによるものであるということが分かった.

\section{REFERENCES}

1) Tanaka H, Phys Rev Lett, 71, 3158 (1993), Phys Rev Lett, 76, 787 (1996). J Phys Condens Matter, 12, R207 (2000).

2) Kume $\mathrm{T}$ et al, Macromolecules, 30, 427 (1997), 30, 7232 (1997). Murase H et al, Macromolecules, 28, 7724 (1995). Moses E et al, Phys Rev Lett, 72, 2037 (1994). Onuki A, Phys Rev Lett, 62, 2472 (1989). Onuki A, Taniguchi T, Yamamoto R, Prog Colloid Poly Sci, 106, 150 (1997).

3) Yamaue T, Taniguchi T, Doi M, Trans Mat Res Soc Jpn, 25, 767 (2000), AIP Conference Proceedings, 519, 584 (1999). Sato ES, Tanaka T, Nature, 358, 482 (1992).

4) Taniguchi T, Onuki A, Phys Rev Lett, 77, 4910 (1996). Onuki A, Taniguchi T, J Chem Phys, 106, 1 (1997). Onuki A, Phys Rev Lett, 62, 2472 (1989), J Phys Soc Jpn, 59, 3423 (1990). 